\title{
Relationship Application Of Professional Nursing Practice Models With The Level Of Working Satisfaction Of Nurses In The MPKP Room Of Lasinrang Pinrang Hospital
}

\author{
Muslimin ${ }^{1}$, Werna Nontji2, Burhanuddin Bahar ${ }^{3}$, Safruddin ${ }^{*}$ \\ Nursing Departement, Stikes Baramuli Pinrang, Indonesia ${ }^{1}$ \\ Department of Master of Management in Nursing, Hasanuddin University,Indonesia ${ }^{2}$ \\ Faculty of Public Health, Hasanuddin University, Indonesia ${ }^{3}$ \\ Management Nursing Departement, Stikes Panrita Husada Bulukumba,Indonesia4
}

*Corresponding Autor : safaryahya1@gmail.com

\begin{abstract}
Professional Nursing Practice Model (MPKP) is a method of comprehensive nursing care in providing quality nursing care. This study aims to investigate the correlation between the implementation of professional nursing practice model and the work satis faction rate the working nurses at the MPKP rom of the Regional Hospital of Lasinrang in Pinrang. The study is analytically observational with cross-sectioanl design. The subject $(n=124)$ are practicing nurses in the inpatient ward of Lasinrang Regional Hospital of Pinrang. The sample was selected employing systematic random sampling technique. The data were obtained with questionnaire distribution and observation checklist and the data were analysed with univariate and bivariate measures. The chi-square test proves that the operand $(\mathrm{p}=0.000)$, pre-Comperence $(\mathrm{p}=0.000)$, comperence $(\mathrm{p}=0.000)$, comperence case $(p=0.164)$, and round $(p=0.164)$ on the work satisfaction rate of the working nurses. This implies that there is a significant correlation the operand evaluation, precomperence, post comperence, and the work satisfaction rate of the working nurses for the value of $\mathrm{p}<0.05$ but no significant correlation between case comperence evaluation as well as round and the work satisfaction of the nurses with $\mathrm{p}>0.05$.
\end{abstract}

Keywords: Professional Nursing Practice Model, Working Nurses

\section{INTRODUCTION}

One of the strategies to optimize the role and function of nurses in nursing services is to carry out nursing management in the hope that an optimal management factor can increase the effectiveness of nursing service distribution while ensuring client satisfaction with nursing services. One of the efforts to provide quality and professional service is the development of a professional nursing practice model (MPKP) that allows professional nurses to manage the provision of nursing care including an environment to support the provision of care. MPKP is very useful for nurses, doctors, patients, and other professions in carrying out nursing care. With MPKP, nurses can understand their duties 
and responsibilities towards patients from entering to leaving the hospital. MPKP implementation must be supported by adequate human resources, facilities, and infrastructure. The process of nursing professionalism in Indonesia began in the 1983 National Workshop. The MPKP that is being developed is structuring the structure and process (system) of providing nursing care at the wardroom level. This MPKP determines the number and types of nursing personnel according to client needs, primary modification methods are used and nursing care standards are established since the beginning of the client's care. The results of quasi-experimental research prove that MPKP implementation can improve the quality of care as assessed by increasing client and family satisfaction, increasing nurse compliance with standards, and decreasing the number of nosocomial infections (Sitorus, 2000).

Several studies on the application of MPKP in Indonesia have provided many benefits for patients and the nursing profession. The management process is a series of systematic resource activities. Coordination and integration of HR through planning, organizing, coordinating, directing, and controlling to achieve specific organizational goals (Marquist \& Huston, 2010). The process of working through the care staff to provide nursing services, treatment, and improve patient comfort (Gillies, 2000). MPKP is a method of providing comprehensive nursing care in the MPKP providing nursing services. This care provides a higher sense of responsibility for nurses, resulting in job satisfaction and patient satisfaction. Job satisfaction is influenced by several factors, including wages, own work, promotion, supervision/supervision, workgroups, and working conditions. Whether or not health services are affected by the level of job satisfaction of hospital employees, satisfied employees tend to work with higher quality, are more productive, last longer, and can create satisfied customers (Ratna S. 2011). A comfortable and conductive work atmosphere is a dominant factor that affects the job satisfaction of nurses over income.

Feelings of satisfaction in helping clients to achieve a degree of health and well-being reflect a nurse's feelings about job satisfaction. Job satisfaction is a pleasant or unpleasant emotional state in which employees view their work. This can be seen in the positive attitude of employees towards work and everything they face in their work environment (Sunyoto, 2013). Research on job satisfaction has been done a lot, with the results showing that many nurses experience job dissatisfaction. Nurses experienced the highest job dissatisfaction in the United States (41\%) followed by Scotland (38\%), United 
Kingdom (36\%), Canada (33\%), and Germany (17\%). One-third of nurses in Scotland and the UK who experienced dissatisfaction and more than a fifth in the United States who experienced dissatisfaction quit their profession within 12 months. Research on job satisfaction of nurses in Indonesia at one of the government hospitals shows that nurse dissatisfaction is $47.1 \%$.

The Lasinrang Regional General Hospital is a type C hospital owned by the Pinrang District Government with a capacity of 167 beds and 106 nurses. The hospital is currently continuing to make improvements to the infrastructure and forming an MPKP model to support the achievement of its vision and mission, however, MPKP is implemented according to the procedures in the MPKP for all inpatient rooms (Unhas Nursing Student Residency). The purpose of this study was to determine the relationship between the application of the MPKP and the level of job satisfaction of the nurses in the MPKP Room at RSUD Lasinrang Pinrang.

\section{MATERIAL AND METHODS}

This type of research is an observational analytic study with a cross-sectional approach that aims to determine the relationship of the application of MPKP with level job satisfaction of nurses in the MPKP Room at the Lasinrang Pinrang Regional Hospital in 2014 which was measured at the same time. The population in this study were all the nurses who served in the Inpatient Room at RSUD Lasinrang Pinrang totaling 146 people. Sampling uses a probability sampling technique, namely Systematic sampling, where the method of taking a simple random sample assumes that certain characteristics possessed by the population are not considered in the study (Dharma K, 2011). The instrument used in this study was a questionnaire, which was created by the researcher concerning the conceptualization. The questionnaire is several questions used to obtain information (Dharma K, 2011). The questionnaire was used to collect data about the application of the MPKP and job satisfaction of nurses.

For data analysis, researchers need several supporting data from inside and outside the field. For this reason, researchers used two kinds of data collection methods, namely primary data. Primary data were collected using a questionnaire. Questionnaires were given to respondents after obtaining permission from the Director of RSUD Lasinrang Pinrang. Secondary Data Obtained or collected by researchers from existing sources, in Lasinrang Pinrang Regional Hospital, namely the number of nurses and MPKP policies. After tabulating data, it is then processed using statistical test methods. Univariate 
analysis Was carried out to get a general description and how to describe each variable used in the study, namely looking at the frequency distribution. Bivariate Analysis Data analysis was shown to answer the research objectives and test the research hypothesis. In this study using the Chi-Square test data

\section{RESULTS}

Table. 1 Frequency Distribution of Respondent Characteristics

\begin{tabular}{lcc}
\hline Characteristics of respondents & Frequency (f) & Percentage (\%) \\
\hline Gender & 4 & 3,2 \\
\hline Male & 120 & 96,8 \\
Female & & \\
\hline Age & 83 & 66,9 \\
\hline 22-30 Year & 36 & 29,0 \\
31-38 Year & 5 & 4,0 \\
39-48 Year & & 0,8 \\
\hline Level Of Education & 1 & 75,0 \\
\hline SPK & 93 & 9,7 \\
DIII & 12 & 11,7 \\
DIV & 14 & 3,2 \\
S1 Nursing & 4 & 43,5 \\
Ners & & 56,5 \\
\hline Working Period & 54 & \\
\hline$\leq 5$ Year & 70 & 29,0 \\
$\geq 5$ Year & & 71,0 \\
\hline Marital Status & 36 & 100,0 \\
\hline Unmerried & 88 & \\
Married & 124 & \\
\hline Amount & & \\
\hline
\end{tabular}

Table 1 shows that most of the respondents in this study were female as many as 120 people (96.8\%), with 83 people between the ages of $22-30$ years (66.9\%), the most education was DIII Nursing as many as 93 people (75.0\%). The most respondents working period is $>5$ years, namely, 70 people (56.5\%) with the most marital status is married as many as 88 people (71.0\%).

Table 2. Frequency Distribution of the Evaluation of the Implementation of the MPKP

\begin{tabular}{lccc}
\hline MPKP Apllication & Evaluation & Frequency (F) & Percentage (\%) \\
\hline Operand & Good & 64 & 51,6 \\
& Not Good & 60 & 48,4 \\
\hline Pre Comfrence & Good & 69 & 55,6 \\
& Not Good & 55 & 44,4 \\
\hline Comperence & Good & 56 & 45,2 \\
& Not Good & 68 & 54,8 \\
\hline Case Comprehence & Good & 78 & 62,9
\end{tabular}




\begin{tabular}{lccc} 
& Not Good & 46 & 37,1 \\
\hline Ronde & Good & 78 & 62,9 \\
& Not Good & 46 & 37,1 \\
\hline Amount & & 124 & 100,0 \\
\hline
\end{tabular}

Table 2 shows that most of the respondents, namely 64 people (51.6\%) carried out operands, 69 people (55.6) carried out pre-conference and 78 people (62.9\%) carried out case conference and 78 people $(62.9 \%) \%$ ) did the round well while 68 people (54.8\%) did it with poor conference.

\section{Table. 3 Frequency Distribution Of Job Satisfaction}

\begin{tabular}{lcc}
\hline Job satisfaction & Frequency (f) & Percentage (\%) \\
\hline Satisfied & 64 & 51,6 \\
Less satisfied & 60 & 48,4 \\
\hline Amount & $\mathbf{1 2 4}$ & $\mathbf{1 0 0 , 0}$ \\
\hline
\end{tabular}

Based on table 3 , it can be seen that the number of respondents who expressed satisfaction were 64 people with a percentage of $51.6 \%$ and 60 people who were less satisfied with a percentage of $48.4 \%$.

Table 4.Operational Evaluation Relationship, Pre-conference Evaluation, Post-Conference Evaluation, Case Comference, and Round Evaluation, with the Satisfaction of Executing Nurses

\begin{tabular}{|c|c|c|c|c|c|c|c|}
\hline & & \multicolumn{4}{|c|}{ Kepuasan kerja } & \multirow{3}{*}{ Amount } & \multirow{3}{*}{$P$ Value } \\
\hline & & \multicolumn{2}{|c|}{ satisfied, } & \multicolumn{2}{|c|}{ not satisfied } & & \\
\hline & & $\mathbf{n}$ & $\%$ & $\mathbf{n}$ & $\%$ & & \\
\hline \multirow[t]{2}{*}{ Operant Evaluation } & Good & 60 & 48,4 & 4 & 3,2 & & 0,000 \\
\hline & Not good & 4 & 3,2 & 56 & 45,2 & & \\
\hline \multirow{2}{*}{$\begin{array}{l}\text { Pre Conference } \\
\text { Evaluation }\end{array}$} & Good & 58 & 46,8 & 11 & 8,9 & 69 & 0,000 \\
\hline & Not good & 6 & 4,8 & 49 & 39,5 & 55 & \\
\hline \multirow{2}{*}{$\begin{array}{l}\text { Post Conference } \\
\text { Evaluation }\end{array}$} & Good & 46 & 37,1 & 10 & 8,1 & 56 & 0,000 \\
\hline & Not good & 18 & 14,5 & 50 & 40,3 & 68 & \\
\hline \multirow{2}{*}{$\begin{array}{l}\text { Case Conference } \\
\text { Evaluation }\end{array}$} & Good & 44 & 35,5 & 34 & 27,4 & 78 & 0,164 \\
\hline & Not good & 20 & 16,1 & 26 & 21,0 & 46 & \\
\hline \multirow[t]{2}{*}{ Evaluation Round } & Good & 44 & 35,5 & 34 & 27,4 & 78 & 0,164 \\
\hline & Not good & 20 & 16,1 & 26 & 21,0 & 46 & \\
\hline
\end{tabular}

Table 4 presents the relationship between Operant Evaluation and Job Satisfaction of the implementing nurses, where there were 60 respondents $(48.4 \%)$ who rated good operants who expressed satisfaction, while 4 people (3.2\%) nurses with poor operant ratings expressed satisfaction, the results of the test analysis. Chi-square obtained a pvalue of $0.0000(\mathrm{p}<0.05)$, which means that there is a significant relationship between Operant Evaluation and job satisfaction of the nurse in charge. Evaluation of the pre- 
conference with the job satisfaction of the implementing nurses, where there were 58 respondents (46.8\%) who had a good pre-conference assessment who said they were satisfied while 11 people (8.9\%) were nurses with a poor pre-conference assessment who stated they were satisfied, the results of the chi test analysis Square obtained p-value 0.000 ( $\mathrm{p}<0.05)$, which means that there is a significant relationship between preconference evaluation and job satisfaction of the nurse in charge.

The relationship between post-conference evaluation and executive nurse job satisfaction, where there are 46 respondents (37.1\%) good post-conference assessment who expressed satisfaction while 10 people (8.1\%) nurses with poor post-conference assessment who expressed satisfaction, test analysis results in Chi-square obtained a pvalue of $0.000(\mathrm{p}<0.05)$, which means that there is a significant relationship between post-conference evaluation and job satisfaction of the nurses. Case Conference with a good number of 78 people, associated with job satisfaction who expressed satisfaction amounted to 44 people (35.5\%) and those who were less satisfied were 34 people (27.4\%). There were less than 46 nurses who carried out the Case Conference, associated with satisfaction, 20 people (16.1\%) who were satisfied, and 26 people less satisfied (21.0\%). The results of statistical tests with chi-square obtained p-value $=0.164(\mathrm{p}$ $<0.05)$. This means that there is no relationship between the Case Conference evaluation and the job satisfaction of the implementing nurses.

The number of good rounds was 78 people, which is related to their job satisfaction who stated that they were satisfied were 44 people (35.5\%) and those who were less satisfied were 34 people (27.4\%). The number of nurses who carried out the Case Conference was less than 46 people, associated with their satisfaction, 20 people $(16.1 \%)$ who expressed satisfaction, and 26 less satisfied people (21.0\%). The results of statistical tests with chi-square obtained $\mathrm{p}$-value $=0.164(\mathrm{p}<0.05)$. This means that there is no relationship between the Rondean evaluation and the job satisfaction of the executive nurse.

\section{DISCUSSION}

In the job satisfaction of implementing nurses, it is related to the implementation of operands, which shows that there are still some nursing nurses where there are 60 respondents (48.4\%) who have a good rating of operands who are satisfied while 4 people (3.2\%) are nurses who still do not apply operands in implementing MPKP. impact on the unsatisfactory job satisfaction of the nurse in charge. From this study, there were 
also a number of respondents who stated that the application of operands was less than 60 nurses (48.4\%) and the job satisfaction of implementing nurses was satisfied 64 (51.6\%), and there was also less job satisfaction at 60 (48.4\%). This usually happens due to many factors faced by the nurse in charge of them is the workload of nurses and heavier which has to look after the patient for 24 hours. As stated by Ilyas (2007), the excessive workload can also interfere with work performance which ultimately has a negative impact on the work satisfaction of the nurse, which automatically affects the quality of her work, for example giving additional tasks that are not in accordance with the nurse's ability such as the number of patients who have to treat, working time and others.

There were several respondents who stated that the implementation of the preconference was good and job satisfaction was good and there were also those who stated that the implementation of the pre-conference was good but their job satisfaction was not enough. This shows that in the job satisfaction of the nurses who still do not apply preconference in the application of MPKP which has an impact on the job satisfaction of the nurse who is less (Mulyani, 2006). Performance is the achievement/achievements of a person with respect to all tasks assigned to him. Likewise in the implementation of the pre-conference held before interacting with patients which is useful in the process of providing nursing care to patients whether it is as planned or not. From the existing theory, the pre-conference is the communication of the team and the executive nurse after completing the operation for the activity plan for the shift led by the team leader or the person in charge of the team. If only one person is assigned to the team, then the preconference is eliminated, the content of the pre-conference is the plan of each nurse (daily plan) and additional plans from the orphanage and PJ team.

The results of this study have similarities with the results of research conducted by Rudiono 2011, regarding the relationship between the application of the team method and the performance of the nurse in the internal hospital room. DR Wahidin Sudirohusodo Makassar, who stated that there was a relationship between the preconference and the performance of the nurses with 46 respondents and those who had a good performance, namely 32 respondents (69.6\%) and those who were less, namely 10 respondents (21.7\%), while those who considered The pre-conference was lacking with good nurse performance, namely 0 respondents and those with less performance, namely 4 respondents (8.7\%), obtained p-value $=0.006$ with $\alpha=0.05$. 
Respondents' job satisfaction in the implementation of a good post-conference was 56 respondents (45.2\%), so the implementation of 10 (ten) post-conference rooms in RSU Lasinrang Pinrang has not fully carried out a post-conference, as well as in carrying out a post-conference which was held after interacting with Patients whose results from the post-conference will be given to the next shift which is useful in the process of providing nursing care to patients in planning further nursing care. Based on the observations made by the researcher, the researcher It is assumed that the postconference should be further improved, especially in communication between nurses and team leaders so that nurses can be more responsible in carrying out nursing care.

In this study, it shows that the implementation of the case conference at the Lasinrang Hospital care unit is generally carried out well with a total of 78 people with a percentage of $62.9 \%$. However, when related to the job satisfaction of nurses, there were 44 people who expressed satisfaction in their work and it was done well. Meanwhile, 26 people (21\%) were not satisfied with the case conference and 20 people $(16.1 \%)$ expressed satisfaction. So that in this study also shows that there is no relationship with the implementation of the case conference with the performance of the nurses at RSU Lasinrang Pinrang with a p-value of 0.164 .

This is different from Estelle's (2011) research, which states that the implementation of a case conference can increase job satisfaction of the nurse in charge. The involvement of the nurse in the implementation of case conferences is a medium in solving cases faced in the implementation of nursing care so that nurses become more comfortable in carrying out their duties.The number of good rounds was 78 people, which is related to their job satisfaction who stated that they were satisfied were 44 people (35.5\%) and those who were less satisfied were 34 people (27.4\%). The number of nurses who carried out the less round was 46 people, associated with their satisfaction, 20 people $(16.1 \%)$ who expressed satisfaction, and 26 people who were less satisfied (21.0\%). The results of statistical tests with chi-square obtained the value of $p=0.164(p<0.05)$. This means that there is no relationship between the evaluation round and the job satisfaction of the nurses.

The results of this study are not in line with the research of Saleh (2012), which states that there is an effect of the nursing round on job satisfaction of nurses in the inpatient room of Abdul Wahab Sjahrenie Hospital Samarinda. According to the assumptions of this researcher, this is because the implementation of the nursing round in each room in the 
Lasinrang Pinrang public hospital has not yet been implemented according to this theory due to various factors, one of which is due to limited knowledge about the nursing round, because the level of education of the nurses in the room is different where it is still mostly dominated by D III Nursing education with a total of 93 people (75\%), compared to S1 Nurses which only amounted to 4 people (3.2\%).

\section{CONCLUSION}

The researcher concludes that to improve the quality of the application of the professional nursing practice model (MPKP), it is necessary to carry out education levels and training of implementing nurses so that the application of the professional nursing practice model goes according to theory so that the quality of nursing services can be improved to ensure job satisfaction of nurses and patients. For researchers, further research can be carried out by connecting the factors that are in the confounding variable to determine the factors that affect the implementation of MPKP with the Job Satisfaction of the Implementing Nurses.

\section{REFERENCES}

Dharma Kelana K. (2011). Metodologi Penelitian Keperawatan. Trans Info Media: Jakarta Estelle. (2011). Pengaruh pelatihan supervise klinik kepala ruangan terhadap kepuasan kerja dan kinerja perawat pelasana di ruang rawat inap Rumah sakit Woodward Palu. Thesis.UI

Gillies Dee Ann. (2000). Manajemen Keperawatan, Sebagai Suatu Pendekatan Sistem, penerjemah Neng Hati Sawiji, Bandung: Yayasan Ikatan Alumni Pendidikan Keperawatan Padjajaran (IAPKP)

Ilyas Yaslis. (2011). Perencanaan SDM Rumah Sakit. FKM UI. Jakarta

Marquis B.L dan Houston C.J. (2010). Kepemimpinan dan Manajemen Keperawatan : Teori \& Aplikasi. Edisi 4, Alih Bahasa Widyawati, Wilda Eka Handayani, Fruriolina Arian., EGC, Jakarta

Mulyani Sri. (2006). Efektivitas sistim pembagian tugas metode tim terhadap penerapan SAK serta kepuasan pasien dan perawat di ruang Model Praktek Keperawatan Profesional (MPKP) RSUD Prof. Margono Soekarjo Purwokerto. Yogyakarta: UGM

Ratna S. (2011). Manajemen keperawatan : manajemen keperawatan di ruang rawat, Sagung seto: Jakarta

SalehZainuddin. (2012). Pengaruh Ronde Keperawatan terhadap kepuasan kerja perawat pelaksana di Ruang Rawat Inap RSUD Abdul Wahhab Sjahranie Samarinda. Thesis.UI 
Sitorus R. (2006). Model Praktik Keperawatan Profesional (MPKP) di Rumah Sakit : Penataan Struktur dan Proses Pemberian Asuhan Keperawatan di Ruang Rawat. Panduan Implementasi, EGC, Jakarta.

Sunyoto D. (2013). Perilaku Organisasi. Yokyakarta : Center for Akademic PublishingService 